Letters

\section{COVID-19 and education in regional anesthesia}

\section{To the Editor}

We read with special interest the recent article by Ashokka et al titled "Reconfiguring the scope and practice of regional anesthesia (RA) in a pandemic: the COVID-19 perspective"1 and we are thankful for its contribution. The concern about the anesthesiologist and healthcare team's safety when performing general anesthesia (GA) is real, due to exposition to aerosolized particles and potential dispersion of the virus during airway-instrumentation. Since COVID-19 transmission has proven to occur from both symptomatic and asymptomatic patients, RA, which is non-aerosol generating, should be considered whenever the surgical procedure and patient's condition are suitable for it. $^{2}$ Ashokka et al wisely recommend preoperative risk stratification with the use of point-of-care ultrasound to assess the extent of COVID-19 disease for therapeutic purposes and to help in the decision making of which patients could potentially receive RA versus GA techniques. ${ }^{1}$ Recommendations on how to perform RA procedures include: performing the procedure in the operating theater, limiting the number of personnel present, and that the most experienced person should execute the procedure. $^{3}$

We would like to call the attention to the fact that these challenging conditions will undoubtedly minimize residents teaching and exposure to RA procedures. As we aim for them to be done by highexperienced clinicians in order to decrease the risk of failure and the possibility of specific complications (Ej. pneumothorax and conversion to GA), ${ }^{4}$ we are also reducing the options of trainees to learn how to perform them. This situation may have important education repercussions, especially in low-income countries whit high-rates of the virus circulating within the community, where all-patients admitted for surgical care are treated as suspects, since preoperative testing is not an available option.

As a consequence, anesthesia residents will experience a dramatic drop in the exposure to all aspects of their RA training, leading to potentially negative effects on their training in the near future. ${ }^{5}$ One of the possibilities to overcome this obstacle is to adapt simulation techniques to ensure high-quality RA education. This needs to be done to maintain safety and wellness of learners, educators and patients.

Virtual education has an important role. Strategies such as watching didactic material and high-quality RA videos prior to periodic teleconferences for questions and discussion, could partially help with the problem. Simulation needs to be encouraged in practicing technical skills in RA procedures and crisis management scenarios. Clinical-simulated situations that include live-threatening conditions also represent an opportunity to practice rapid control of airway and cardiopulmonary resuscitation with the appropriate use of personal protective equipment amidst the lack of operative cases. ${ }^{1}$ During this rapidly evolving crisis, a great deal of flexibility will be required from both learners and educators, by offering alternative approaches, allowing free and easy access to surgical video libraries, and encouraging RA societies to share their resources with residency programmes and anesthesiologist in order to maintain rigorous standards of education and training in RA procedures.

\section{Angela María Ríos Medina, ${ }^{1}$ Juliana Caicedo Salazar ${ }^{2}$}

${ }^{1}$ Risaralda, Comfamiliar Risaralda, Pereira, Pereira, Colombia

${ }^{2}$ Anesthesia Department, Clinica Comfamiliar, Pereira, Risaralda, Colombia

Correspondence to Dr Angela María Ríos Medina, Risaralda, Comfamiliar Risaralda, Pereira, Colombia; lunavero@yahoo.com

Contributors All persons who meet authorship criteria are listed as authors, and all authors certify that they have read and accepted the conditions of the current instructions to authors. All the authors have seen and agreed to the submitted version of the paper and participated sufficiently in the work to take public responsibility for the content, including participation in the concept, design, analysis, writing, drafting and revision of the manuscript. Furthermore, each author certifies that this material is original and has not been and will not be submitted to or published in any other publication simultaneously.

Funding The authors have not declared a specific grant for this research from any funding agency in the public, commercial or not-for-profit sectors.

Competing interests None declared.

Patient consent for publication Not required.

Provenance and peer review Not commissioned; internally peer reviewed.

\section{(2) OPEN ACCESS}

Open access This is an open access article distributed in accordance with the Creative Commons Attribution Non Commercial (CC BY-NC 4.0) license, which permits others to distribute, remix, adapt, build upon this work non-commercially, and license their derivative works on different terms, provided the original work is properly cited, an indication of whether changes were made, and the use is non-commercial. See: http:// creativecommons.org/licenses/by-nc/4.0/.

(C) American Society of Regional Anesthesia \& Pain Medicine 2021. Re-use permitted under CC BY-NC. No commercial re-use. Published by BMJ.

\section{(A) Check for updates}

To cite Ríos Medina AM, Caicedo Salazar J. Reg Anesth Pain Med 2021;46:550.

Received 20 June 2020

Accepted 22 June 2020

Published Online First 14 July 2020

Reg Anesth Pain Med 2021;46:550.

doi:10.1136/rapm-2020-101838

\section{REFERENCES}

1 Ashokka B, Chakraborty A, Subramanian BJ, et al. Reconfiguring the scope and practice of regional anesthesia in a pandemic: the COVID-19 perspective. Reg Anesth Pain Med 2020;45:536-43.

2 Lie SA, Wong SW, Wong LT, et al. Practical considerations for performing regional anesthesia: lessons learned from the COVID-19 pandemic. Can J Anaesth 2020;67:885-92.

3 Uppal V, Sondekoppam RV, Lobo CA, et al. Practicerecommendations on neuroaxial-anesthesia and peripheral nerve-blocks during the COVID-19-pandemic 2020. Available: https://esraeurope.org/wp-content/ uploads/2020/04/ESRAASRA-COVID-19- Guidelinespdf [Accessed 1 May 2020].

4 Macfarlane AJR, Harrop-Griffiths W, Pawa A. RegionalAnaesthesia and COVID-19: first-choice at last? British Journal of Anaesthesia.

5 NYSORA (New York School of Regional Anesthesia). Regional anesthesia in the COVID-19 pandemic, 2020. Available: https://www.nysora.com/news/regionalanesthesia-in-the-covid-19-pandemic/ 